\title{
Clinico-pathological study of cutaneous adnexal cyst with some unusual presentation
}

\author{
Praneeta Jaswant Singh ${ }^{1}$, Himani Dahiya ${ }^{1}$ \\ ${ }^{I}$ Department of Pathology, KD Medical college hospital and research center, Uttar Pradesh, India
}

\section{Keywords:}

Apocrine hidrocystoma; Cysticercosis Dermoid Cyst; Epidermal cyst; Proliferating trichilemmal cyst; Trichilemmal cyst;

\begin{abstract}
Background: Cutaneous cysts are slow-growing benign intradermal or subcutaneous tumors that occur commonly in the hair-bearing areas of the body. Sometimes they occur in non-hair-bearing areas due to traumatic implantation of the epidermis. The present study was conducted to determine the prevalence of various cutaneous cysts in our hospital set up, to record an unusual presentation and clinicohistopathological correlation.

Materials and Methods: This is a hospital-based retrospective analysis of cutaneous cysts conducted for 6 months. All skin biopsies diagnosed under the category of the cutaneous cyst were included in the study. Histopathology slides stained with Hematoxylin and eosin were analyzed.

Results: A total of 185 cases of cutaneous cysts were included in the study. The most frequent cutaneous cyst was epidermal cyst $(75.13 \%)$ followed by dermoid cyst $(18.38 \%)$. Epidermal cysts occurred at unusual locations of the palm, lower extremity, and breast. Unusual locations of the dermoid cyst were the floor of the mouth, gluteal region, scalp, and back. Two cases of scrotal epidermal cysts were associated with idiopathic calcinosis of the scrotum. In one case each of proliferating trichilemmal cyst and apocrine hidrocystoma occurred over the unusual location of the back while cysticercosis occurred at an unusual location of the scalp. Inflammatory changes were found in 27 cases (14.59\%) of cutaneous cysts. An overall clinicopathological correlation was seen in $91.89 \%(170 / 185)$ cases of cutaneous cysts.
\end{abstract}

Conclusion: Unusual clinical presentation of cutaneous cysts can pose a diagnostic dilemma. Definitive diagnosis in such cases is possible by histopathological analysis.

\section{Correspondence:}

Dr. Praneeta Jaswant Singh, MD

Associate Professor, Department of Pathology,

KD Medical college hospital and research center, Uttar Pradesh. India ORCID ID: 0000-0001-6048-6354

Email: pranita.singh123@gmail.com

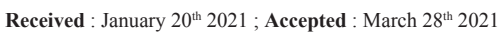

Citation: Singh PJ, Dahiya H. Clinico-pathological study of cutaneous adnexal cyst with some unusual presentation. Journal of Pathology of Nepal. 2021;11(2): 1835-1842. DOI: 10.3126/jpn. v11i2.34396

Copyright: This is an open-access article distributed under the terms of the Creative Commons Attribution 4.0 International License, which permits unrestricted use, distribution, and reproduction in any medium, provided the original author and source are credited.

\section{INTRODUCTION}

The majority of the cutaneous cysts are slow-growing benign intradermal or subcutaneous tumors arising from dermal appendages. They most commonly occur in hair-bearing areas of the body but sometimes they also arise in non-hair bearing areas due to traumatic implantation of the epidermis. Usually they present as asymptomatic painless nodules but sometimes a cyst may rupture and a patient may present with signs and symptoms of inflamed cyst such as redness, tenderness, etc. Over the years dermatopathologists have used different ways to classify cutaneous cysts. ${ }^{1}$ Weedon classified cutaneous cysts as appendageal, developmental, miscellaneous, and lymphatic while Barnhill classified 
them based on the type of cells lining the cyst wall. ${ }^{1}$

Epidermal cysts lined by stratified squamous epithelium are the most common type of cutaneous cyst that has a predilection for the face, trunk, and neck. ${ }^{2}$ Epidermal cysts arising in a scrotal region often undergo calcification which may result in calcinosis cutis. ${ }^{3}$ Other cutaneous cysts are dermoid cysts, trichilemmal cysts, apocrine hidrocystoma, etc. The dermoid cysts are seen along the line of embryonic fusion and show the presence of dermal appendages in their wall. The trichilemmal cyst is also lined by stratified squamous epithelium with an absent granular layer and abrupt keratinization without the formation of keratohyaline granules. The cutaneous cysts like structures that lack epithelial lining are known as pseudocyst and are lined by granulation tissue or inflammatory cells. ${ }^{4}$

A review of the literature shows various case reports on the cutaneous cyst, however, there are only a handful of original research studies dealing with the cutaneous cyst. ${ }^{5,6}$ This study was conducted to determine the prevalence of various cutaneous cysts in our hospital set up, to record any unusual presentation and clinico-histopathological correlation.

\section{MATERIALS AND METHODS}

This was a hospital-based retrospective study conducted in the Department of Pathology at a tertiary care hospital located in North India. The study is approved by Institutional Ethics Committee (IEC). The study was conducted over a period of 6 months from July 2020 to December 2020. A total 185 cases of skin biopsy diagnosed as cutaneous cysts and pseudocysts were included in the study. The clinical data like age, sex, location of the lesion, and provisional clinical diagnosis were retrieved from the requisition form. Special attention was given to any unusual presentation pertaining to the site of a cutaneous cyst, age, and gender of the patients. Gross analysis of the specimen included the size of the specimen, the content of the cyst, color, and thickness of the cyst wall. Microscopic findings were recorded by studying the slides stained with Hematoxylin and eosin. A special stain like Ziehl Neelsen (ZN) was applied wherever necessary. These were further sub-classified based on the type of inflammatory response seen in their wall. Cutaneous cyst lacking epithelial lining but instead lined by granulation tissue, fibrocollagenous stroma, and inflammatory cells were classified as a pseudocyst. The miscellaneous category included parasitic cyst and cutaneous endometriosis. The data was analyzed by using a Microsoft Excel sheet.

\section{RESULTS}

Among the study population, the age-wise distribution of cutaneous cysts showed that the youngest patient was 18 months old while the eldest was 76 years old. Overall cutaneous cyst cases were most frequently seen in the young adult belonging to the age group 20-39 years as shown in table 1 .

Gender-wise distribution of cutaneous cysts showed male predominance with a male to female ratio of 117:68. However single case each of apocrine hidrocystoma and the parasitic cyst was reported in females. Trichilemmal cyst showed female predominance with a male to female ratio of 1:3. Pseudocyst and miscellaneous cysts cases showed an equal male to female ratio.

The most frequent cutaneous cyst was an epidermal cyst (139 cases, $75.13 \%$ ) followed by a dermoid cyst (34 cases, $18.37 \%)$. Inflammatory changes were found in 27 cases (14.59\%) of cutaneous cysts as shown in table no.2 and figure 1. An overall clinicopathological correlation was seen in $91.89 \%(170 / 185)$ cases of cutaneous cysts. Clinical diagnoses in nonconcordant cases were lipoma, umbilical polyp, papilloma, plunging ranula, and tubercular infection. Tubercular infection was suspected in cases of the epidermal cyst and dermoid cyst with sinus formation.

Distribution of cutaneous cyst according to the anatomic location showed that face $(30.27 \%, 56$ cases $)$ was the most common site as shown in table 3 .

The most common site of epidermal cysts was the face (36/139 cases, $25.90 \%)$ followed by trunk (33/139 cases, $17.83 \%$ ) and lower extremities (20/139 cases, $14.38 \%$ ). Epidermal cysts occurred at unusual locations of palm, palmar aspect of index and ring finger, gluteal region, thigh, leg, foot, and breast. All three cases of epidermal cyst involving the palmar aspect of the hand and fingers were reported in adult males in the age group of 45-60 years, measuring $>1 \mathrm{~cm}$ in the greatest dimension. The palmar cyst was quite large measuring 4.5 in the greatest dimension.

Out of five cases of scrotal epidermal cysts, two were

Table 1: Age-wise distribution of cysts

\begin{tabular}{lcccccccc}
$\begin{array}{c}\text { Age } \\
\text { group }\end{array}$ & $\begin{array}{c}\text { Epidermal } \\
\text { cyst (\%) }\end{array}$ & $\begin{array}{c}\text { Dermoid cyst } \\
\mathbf{( \% )}\end{array}$ & $\begin{array}{c}\text { Trichilemmal } \\
\text { cyst (\%) }\end{array}$ & $\begin{array}{c}\text { Proliferating } \\
\text { trichilemmal } \\
\text { cyst (\%) }\end{array}$ & $\begin{array}{c}\text { Pseudo cyst } \\
(\%)\end{array}$ & $\begin{array}{c}\text { Apocrine } \\
\text { hidrocystoma } \\
(\%)\end{array}$ & $\begin{array}{c}\text { Miscellaneous } \\
(\%)\end{array}$ & $\begin{array}{c}\text { Total }(\%) \\
\text { n=185 }\end{array}$ \\
\hline $\mathbf{0 - 1 9}$ & $23(12.43)$ & $14(7.56)$ & - & - & $01(0.54)$ & - & - & $38(20.54)$ \\
\hline $\mathbf{2 0 - 3 9}$ & $62(33.51)$ & $14(7.56)$ & $01(0.54)$ & - & $02(1.08)$ & $01(0.54)$ & $02(1.08)$ & $82(44.32)$ \\
\hline $\mathbf{4 0 - 5 9}$ & $45(24.32)$ & $06(3.24)$ & $02(1.08)$ & $01(0.54)$ & $01(0.54)$ & - & - & $55(29.72)$ \\
$\mathbf{6 0 - 7 9}$ & $09(4.86)$ & - & $01(0.54)$ & - & - & - & - & $10(5.40)$
\end{tabular}


Table 2: Classification of Cutaneous cysts based on the type of the cell lining and inflammatory reaction present in the wall.

\begin{tabular}{|c|c|c|c|c|c|}
\hline Type of cyst & & & & No. of cases (\%) & $\begin{array}{l}\text { Clinic-histopathological } \\
\text { correlation }(\%)\end{array}$ \\
\hline \multirow{15}{*}{ 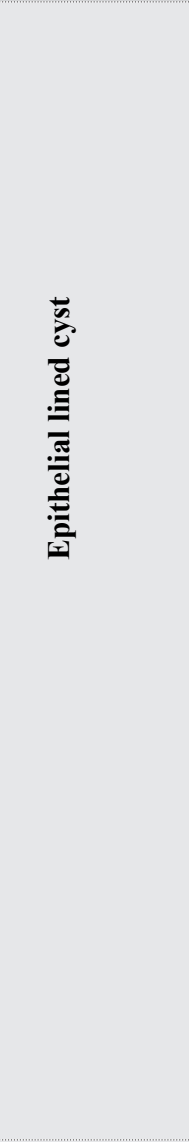 } & \multirow{10}{*}{ 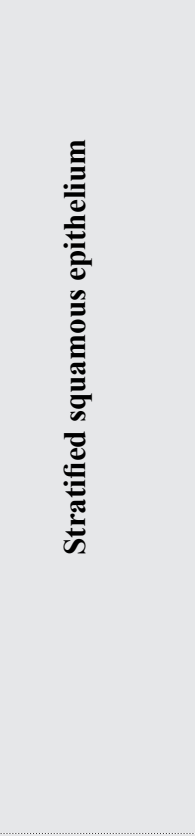 } & \multirow{8}{*}{ 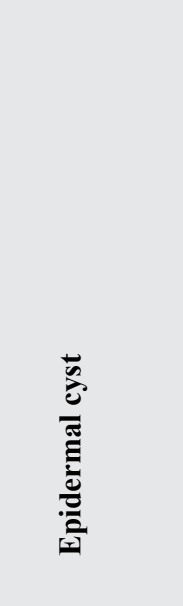 } & With giant cell reaction & $03(1.62)$ & $03(100)$ \\
\hline & & & $\begin{array}{l}\text { With nonspecific } \\
\text { inflammatory response }\end{array}$ & $11(5.94)$ & $10(90.90)$ \\
\hline & & & $\begin{array}{l}\text { With cholesterol } \\
\text { granuloma }\end{array}$ & $02(1.08)$ & $02(100)$ \\
\hline & & & $\begin{array}{l}\text { With } \\
\text { xanthogranulomatous } \\
\text { reaction }\end{array}$ & $01(0.54)$ & $00(0)$ \\
\hline & & & $\begin{array}{l}\text { With foreign body } \\
\text { granuloma }\end{array}$ & $03(1.62)$ & $03(100)$ \\
\hline & & & $\begin{array}{l}\text { Ruptured with } \\
\text { granulomatous response }\end{array}$ & $01(0.54)$ & $01(100)$ \\
\hline & & & $\begin{array}{l}\text { With Idiopathic calcinosis } \\
\text { of scrotum }\end{array}$ & $02(1.08)$ & $02(100)$ \\
\hline & & & Total & $116(62.70)$ & $113(97.41)$ \\
\hline & & $\begin{array}{c}\text { Trichilemmal } \\
\text { cyst }\end{array}$ & $\begin{array}{l}\text { With Cholesterol and } \\
\text { foreign body granuloma } \\
\text { with giant cell reaction }\end{array}$ & $01(0.54)$ & 01(100) \\
\hline & & $\begin{array}{c}\text { Proliferating } \\
\text { trichilemmal } \\
\text { cyst }\end{array}$ & & $01(0.54)$ & $00(0)$ \\
\hline & \multirow{4}{*}{$\begin{array}{c}\text { Stratified } \\
\text { squamous } \\
\text { with adnexal } \\
\text { component in } \\
\text { cyst wall }\end{array}$} & \multirow{4}{*}{ Dermoid cyst } & $\begin{array}{l}\text { With Non specific } \\
\text { inflammation }\end{array}$ & $03(1.62)$ & $03(100)$ \\
\hline & & & With Giant cell reaction & $04(2.16)$ & $04(100)$ \\
\hline & & & With Sinus tract formation & $01(0.54$ & $01(100)$ \\
\hline & & & Total & $26(14.05)$ & $24(92.30)$ \\
\hline & $\begin{array}{l}\text { Cuboidal } \\
\text { epithelium }\end{array}$ & $\begin{array}{c}\text { Apocrine } \\
\text { hidrocystoma }\end{array}$ & & $01(0.54$ & $00(00)$ \\
\hline $\begin{array}{l}\text { Cyst not lined } \\
\text { by epithelium }\end{array}$ & $\begin{array}{l}\text { Inflammatory } \\
\text { pseudocyst }\end{array}$ & & & $04(2.16)$ & 00 \\
\hline \multirow[b]{2}{*}{ Miscellaneous } & Parasitic cyst & & & $01(0.54)$ & 00 \\
\hline & $\begin{array}{c}\text { Cutaneous } \\
\text { endometriosis }\end{array}$ & & & $01(0.54)$ & 00 \\
\hline Total & & & & 185 & $170(91.89)$ \\
\hline
\end{tabular}

associated with idiopathic calcinosis of the scrotum as shown in figure 2. Total 17 cases of giant epidermal cysts measuring $5 \mathrm{~cm}$ or more in diameter were reported. The most common site of the giant epidermal cyst was the lower extremity ( 6 cases) followed by 5 cases over the trunk ( 5 cases) and 3 cases each over the face and scalp.

The most common site, of dermoid cyst was the face (18/34 cases, $52.94 \%)$, followed by scalp (08/34 cases, $23.52 \%)$ and neck (03/34 cases, $8.82 \%)$. Unusual locations of the dermoid cyst were the floor of the mouth, gluteal region, scalp, and back. A ten-year-old male child presented with a sinus tract along with a cyst measuring $3 \mathrm{~cm}$ in diameter over his left buttock. The provisional clinical diagnosis, in this case, was dermoid cyst which was confirmed upon histopathological examination. An eighteen-year-old boy presented with a large swelling on the floor of his mouth. His provisional clinical diagnosis was plunging ranula. The gross examination revealed a giant cyst measuring $5 \times 3 \times 2.5$ $\mathrm{cm}$ and containing pultaceous material. Histopathological examination showed cyst lined by keratinized stratified squamous epithelium along with dermal adnexa thus confirming the diagnosis of dermoid cyst. The rest of the 4 cases of giant dermoid cysts occurred over the forehead.

The most common site for trichilemmal cyst was the scalp (two cases, 50\%) while two cases occurred at an unusual location of the postauricular region and anterior midline neck region. Post auricular trichilemmal cyst was giant measuring $7 \times 4 \times 4 c m$. 


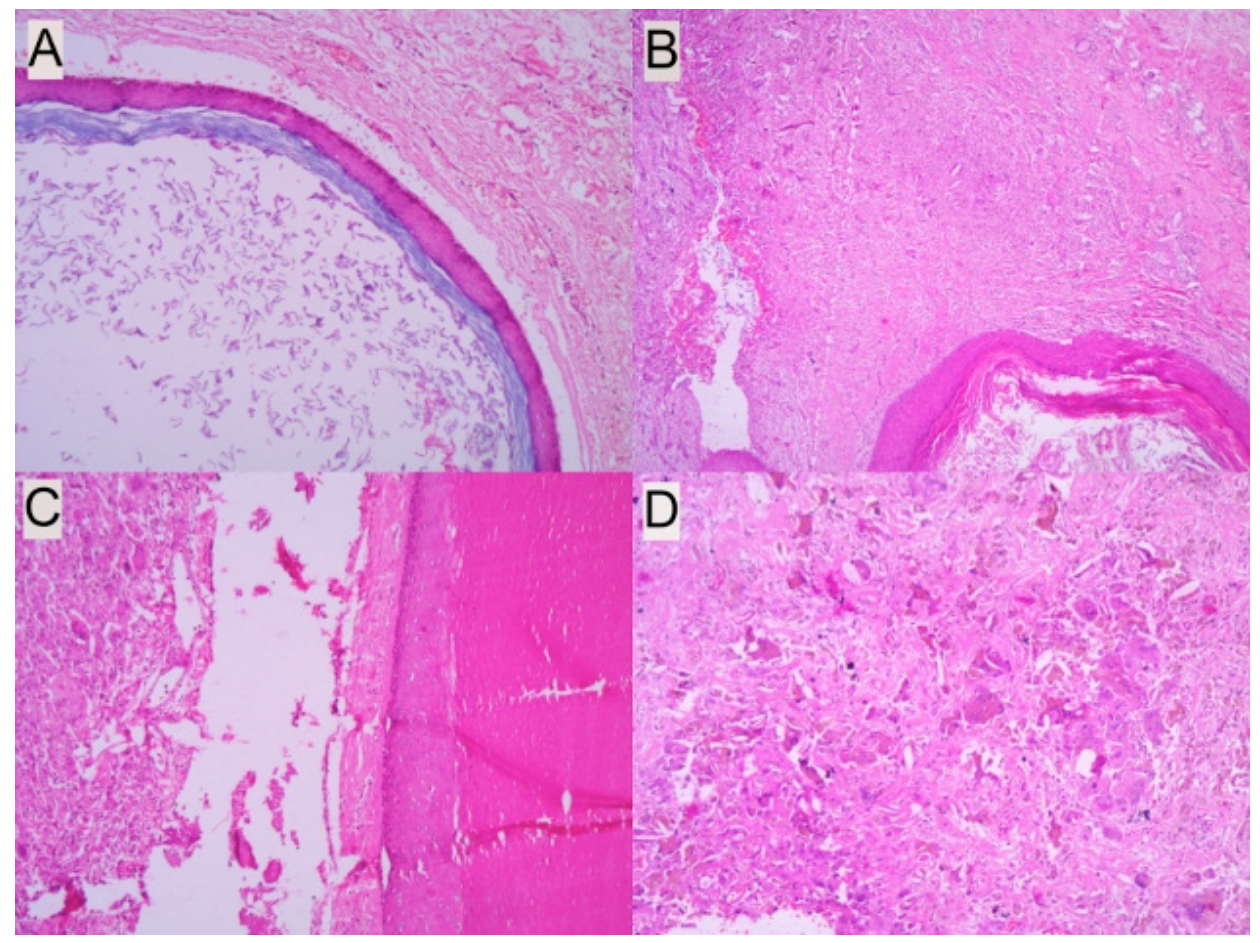

Figure 1: A) Epidermal cyst containing keratin flakes (HE stain, X100). B) Epidermal Cyst with cholesterol granuloma (HE stain, X100). C: Trichilemmal cyst showing abrupt keratinization and cholesterol granuloma (HE stain, X100). D) Giant cell reaction is seen in epidermal cyst (HE stain, X100)

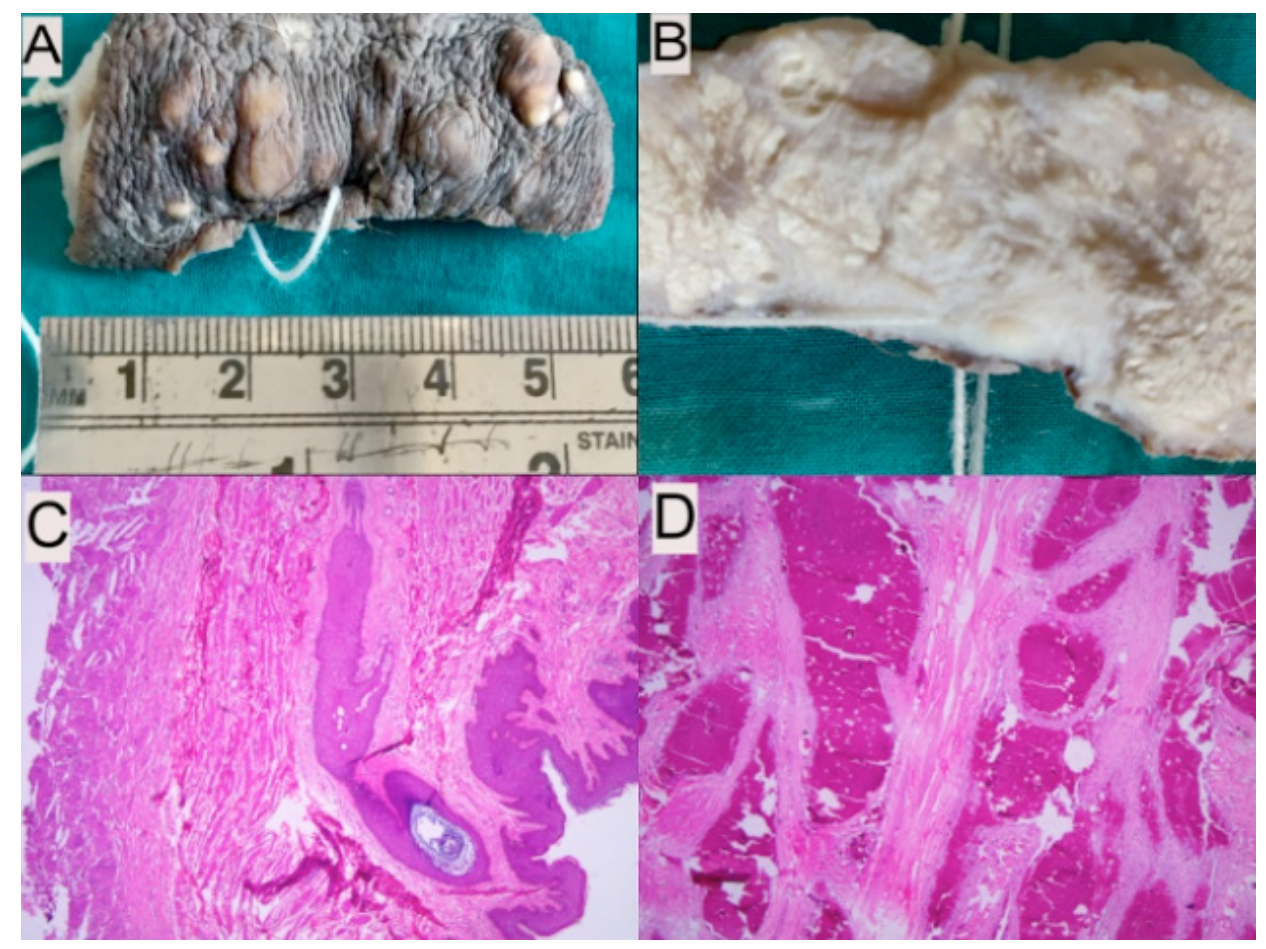

Figure 2: Scrotal epidermal cyst with idiopathic calcinosis of scrotum: (A) External surface showing multiple cysts and nodules over scrotum. (B) Inner surface showing areas of calcification. (C): Epidermal cyst (HE stain, X100). (D) Foci of calcification (HE stain, X100).

One case each of proliferating trichilemmal cyst(PTC) and apocrine hidrocystoma was reported at an unusual location of the back (fig. 3A,B). Proliferating trichilemmal cyst occurred in a 50-year-old man who presented with fungating papillomatous mass measuring $3 \times 2 \times 2 \mathrm{~cm}$ over back with a clinical diagnosis of papilloma.

A large apocrine hidrocystoma measuring $3 \mathrm{~cm}$ in diameter occurred on the back of a 35-year-old woman. The provisional clinical diagnosis was an epidermal cyst. Its 


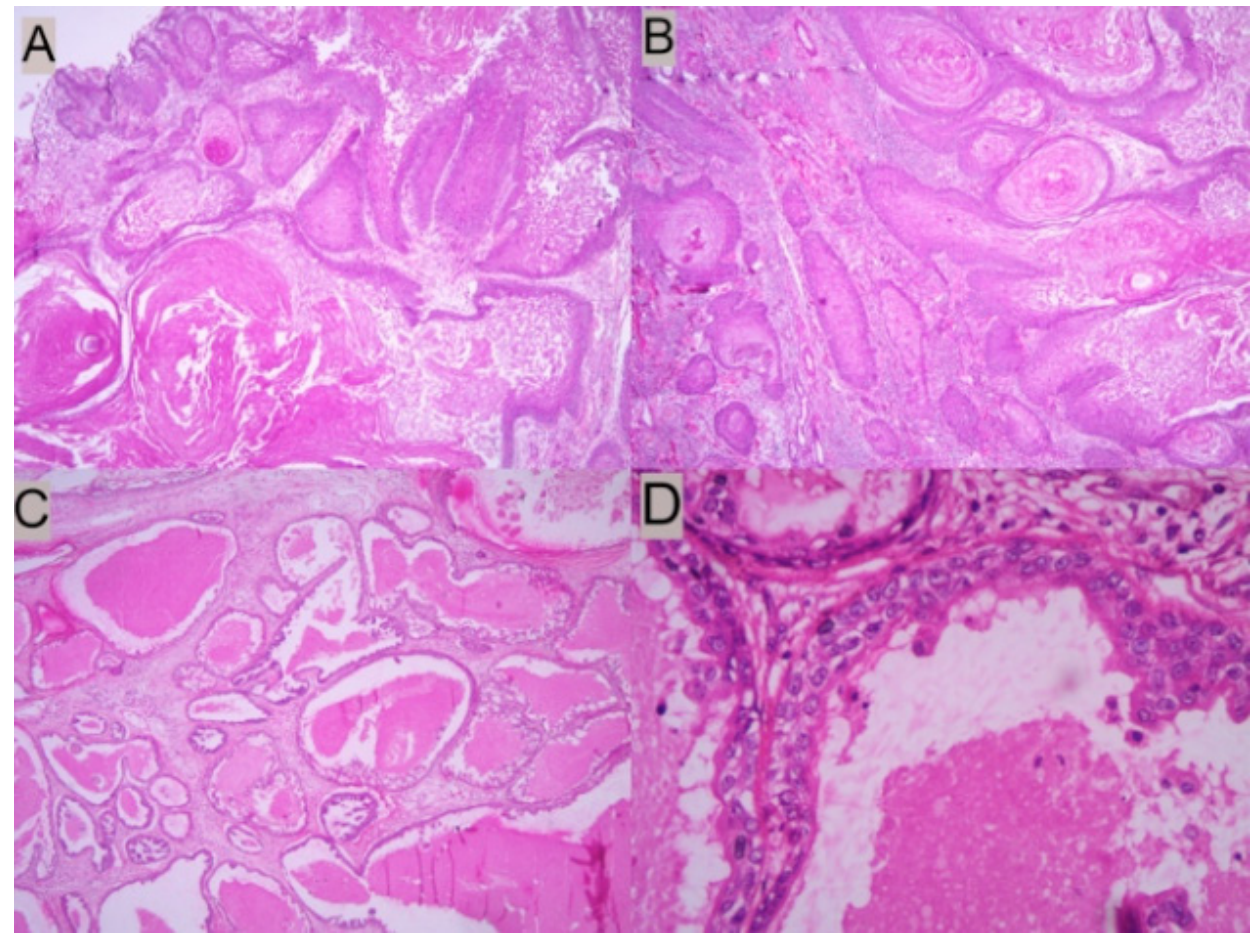

Figure 3:A, B: Proliferating trichilemmal cyst (HE stain, X100). C, D: Apocrine hidrocystoma showing multiloculated cysts lined by the inner layer of cuboidal epithelium with decapitating secretion and outer layer of flattened myoepithelial cells (HE stain, X100; D: HE stain, X400).

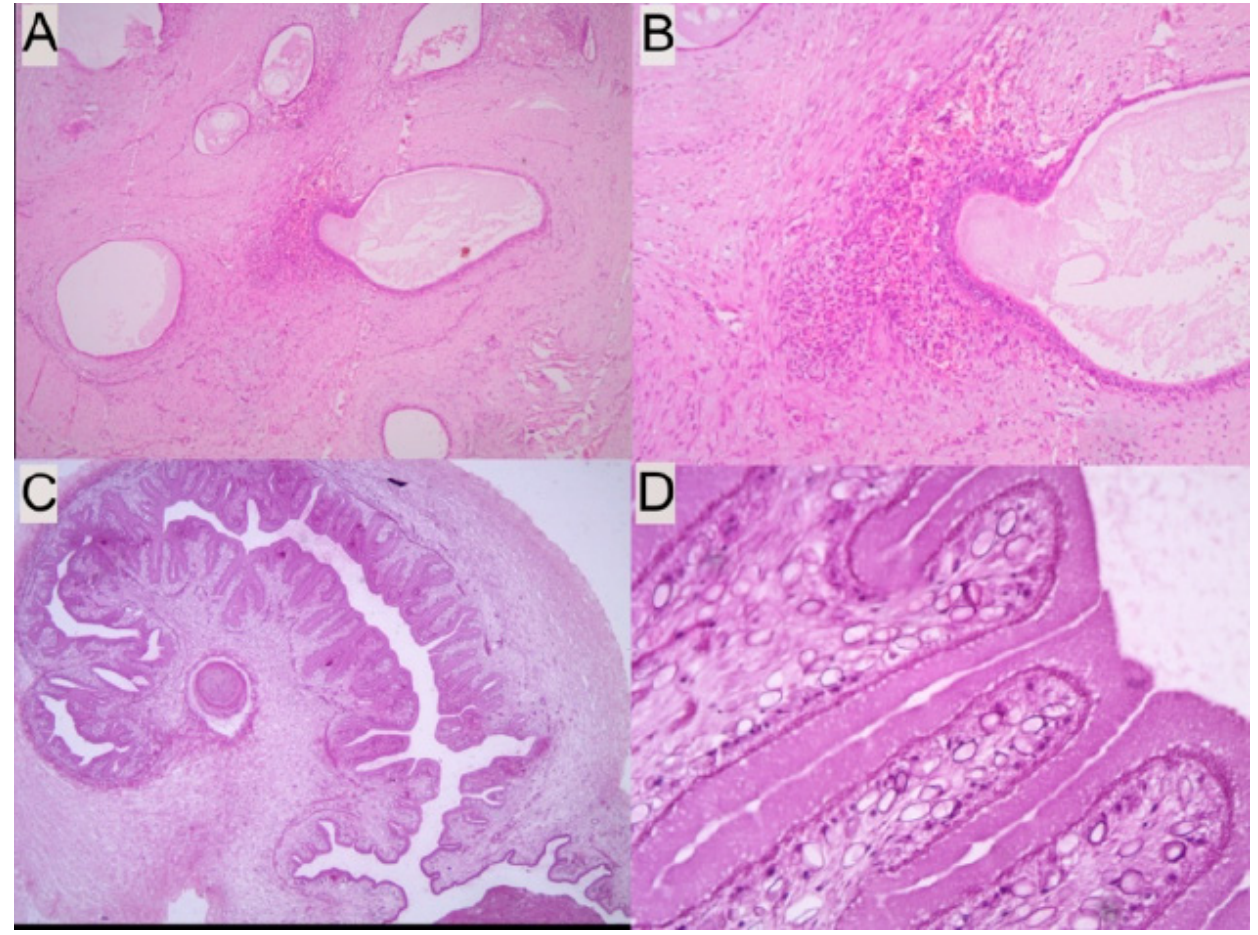

Figure 4A, B: Cutaneous endometriosis showing endometrial glands and stroma: $A$ (H and E, X10) and B (H and E, X 40). C, D: Cysticercosis of scalp showing cystic cavity containing invaginated scolex and suckers: C (HE stain, X100) and D (HE stain, X400)

gross examination showed multiple tiny cysts on the cut surface and microscopic examination showed multiloculated cysts lined by an inner layer of cuboidal epithelium showing decapitation, focal stratification, and papillary projection into the lumen and outer layer of flattened myoepithelial cells. Lumen contained eosinophilic decapitating secretion with cyst macrophages and cholesterol cleft (fig. 3C,D).

A case of cutaneous endometriosis was reported in a 22-yearold woman who presented with soft cystic swelling in the 
Table 3: Distribution of Cutaneous cysts cases according to anatomic location

\begin{tabular}{|c|c|c|c|c|c|c|c|c|}
\hline & \multirow[b]{2}{*}{ Anatomic location } & \multicolumn{7}{|c|}{ Type of cyst } \\
\hline & & $\begin{array}{l}\text { Epidermal } \\
\text { cyst }(\%)\end{array}$ & $\begin{array}{l}\text { Dermoid } \\
\text { cyst }(\%)\end{array}$ & $\begin{array}{l}\text { Trichilemmal } \\
\text { cyst }(\%)\end{array}$ & $\begin{array}{c}\text { Inflammatory } \\
\text { cyst }(\%)\end{array}$ & $\begin{array}{l}\text { Proliferating } \\
\text { trichilemmal } \\
\text { cyst }(\%)\end{array}$ & $\begin{array}{c}\text { Apocrine } \\
\text { hidrocystoma } \\
(\%)\end{array}$ & Misc. (\%) \\
\hline \multirow{9}{*}{ 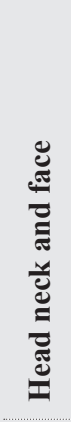 } & Scalp & $12(6.48)$ & $8(4.32)$ & $2(1.08)$ & $1(0.54)$ & - & - & $1(0.54)$ \\
\hline & Forehead & $13(7.02)$ & $12(6.48)$ & - & - & - & - & - \\
\hline & Eyelid & $2(1.08)$ & $1(0.54)$ & - & - & - & - & - \\
\hline & Nose & $2(1.08)$ & $2(1.08)$ & - & - & - & - & - \\
\hline & Cheek & $16(8.64)$ & - & - & - & - & - & - \\
\hline & Post auricular & $1(0.54)$ & $2(1.08)$ & $1(0.54)$ & $1(0.54)$ & - & - & - \\
\hline & Pre auricular & $2(1.08)$ & - & - & - & - & - & - \\
\hline & Neck & $9(4.86)$ & $3(1.62)$ & $1(0.54)$ & - & - & - & - \\
\hline & Floor of the mouth & - & $1(0.54)$ & - & - & - & - & - \\
\hline \multirow{3}{*}{ 兰 } & Anterior abdominal wall & $15(8.10)$ & $1(0.54)$ & - & - & - & - & - \\
\hline & Chest & $18(9.72)$ & - & - & $1(0.54)$ & - & - & - \\
\hline & Back & $17(9.18)$ & $3(1.62)$ & - & - & $1(0.54)$ & - & - \\
\hline \multirow{4}{*}{ 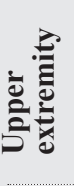 } & Arm & $2(1.08)$ & - & - & - & - & - & - \\
\hline & Axilla & $1(0.54)$ & - & - & - & - & - & - \\
\hline & Palm & $1(0.54)$ & - & - & - & - & - & - \\
\hline & Palmar aspect of Fingers & $2(1.08$ & - & - & - & - & - & - \\
\hline \multirow{4}{*}{ 爮 } & Gluteal region & $6(3.24)$ & $1(0.54)$ & - & $1(0.54)$ & - & - & - \\
\hline & Thigh & $7(3.78)$ & - & - & - & - & - & - \\
\hline & Leg & $5(2.70)$ & - & - & - & - & - & - \\
\hline & Foot & $2(1.08)$ & - & - & - & - & - & - \\
\hline \multicolumn{2}{|c|}{ Breast } & $1(0.54)$ & - & - & - & - & - & - \\
\hline \multicolumn{2}{|c|}{ Scrotum } & $5(2.70)$ & - & - & - & - & - & - \\
\hline
\end{tabular}

inguinal region over a previous hysterectomy scar site. Her provisional clinical diagnosis was a fibrous cyst. However histopathological examination revealed the presence of nonneoplastic endometrial gland and stroma as shown in figure 4. A single case of cysticercosis of the scalp was reported in a 22-year-old male, who was otherwise asymptomatic. His provisional clinical diagnosis was an epidermal cyst. The gross examination showed a $0.6 \mathrm{~cm}$ white-colored cyst containing clear fluid. Its microscopic examination revealed a cystic cavity containing a larval form of the parasite in form of a scolex with hooklets and suckers (fig. 4).

Clinical diagnosis in all four cases $(2.16 \%)$ of pseudocyst was a sebaceous cyst or dermoid cyst. Two of them were received in an already cut open state in a form of a cyst wall. In remaining two cases of pseudocysts, one showed a cystic cavity filled with yellow fluid and another was filled with a viscous white jelly-like material. On microscopy, no epithelial cell lining was seen in all four cases. These cysts were lined either by fibrocollagenous stroma or inflammatory cells. In one case areas of calcification were seen in the wall.

\section{DISCUSSION}

Most common cutaneous cysts like epidermal and dermoid cysts rarely arise in the non-hair-bearing regions of the body like palm, sole, breast, and genitalia.

In the present study, cutaneous cysts showed a male predominance. In contrast to this, a previous study by AlKhateeb $\mathrm{TH}$ et al. ${ }^{5}$ reported female predominance, and Kamyab et al. ${ }^{6}$ reported equal distribution of cutaneous cysts among males and females. Our study was conducted in north India where females rarely visit the hospital for minor ailments like an asymptomatic cutaneous cyst. This could be the reason for male predominance in our study.

In the present study, the face was the most frequent site affected by cutaneous cysts with the epidermal cyst being the most common lesion. These findings are in concordance with the study done by Kamyab et al. ${ }^{6}$ While Al-Khateeb $\mathrm{TH}$ et al. ${ }^{5}$ reported scalp as the most common location of cutaneous cysts with trichilemmal cyst being the most frequent lesion.

In the present study, the most common lesion was the epidermal cyst $(75.13 \%)$ which is in concordance with the previous studies. 5 ,6 The unusual locations of epidermal cyst in the present study were palm, palmar aspect of the finger, gluteal region, thigh, leg, foot, and breast. The etiology of epidermal cyst occurring on hand includes traumatic 
implantation of skin into the underlying tissue or activation of resting embryonic epithelial cells by trauma. Incidence of epidermal cyst among tumors of the hand reported by previous studies varies between 1 to $16 \%$. Lincoski et al. ${ }^{7}$ reported that epidermal cyst occurred more frequently over the palm and palmar aspect of fingers in comparison to the dorsal location with a left-sided predominance. They also reported male predominance with a mean age of 46 years. These findings are in concordance with our study.

Epidermal cysts usually measure a few millimeters to 4 $\mathrm{cm}$ in size while those measuring $>5 \mathrm{~cm}$ are termed giant cysts. ${ }^{4}$ In the present study, cases of giant epidermoid cysts were reported at an unusual location of the foot. The plantar epidermal cyst can arise from eccrine ducts infected with Human Papilloma Virus (HPV 60) infection that may result in migration of its epithelium into the dermal portion leading to the formation of an epidermal cyst. ${ }^{4}$ However there were no signs of HPV infection in our cases.

Idiopathic calcinosis of the scrotum is an uncommon condition that usually presents as asymptomatic multiple nodules of varying sizes. There are many theories pertaining to its etiopathogenesis and some authors have challenged its idiopathic nature. A review of the literature showed that it is considered as dystrophic calcification of epidermal cyst involving scrotum leading to calcinosis cutis. ${ }^{8,9}$ While other authors suggested it to be a dystrophic calcification of dartos muscle. ${ }^{10}$ In the present study, remnants of the epidermal cysts were seen in association with calcified nodules so these cases were included under the category of an epidermal cyst.

Epidermal cyst of a breast is a rare benign disease with only a few cases reported in the English literature. Its etiopathogenesis includes traumatic implantation of the epidermis deep into the breast parenchyma, squamous metaplasia of ductal epithelium owing to some underlying pathological condition like duct ectasia or fibrocystic disease, obstruction of a hair follicle or it may be a congenital cyst arising from embryonic cell rest. ${ }^{11,12}$ It occurs usually in the fifth decade of life. These findings are in concordance with the present study.

In the present study dermoid cyst showed an equal distribution of cases among children and young adults with a predilection for a forehead. Al-Khateeb TH et al. ${ }^{5}$ reported that dermoid cyst was most frequent in the first decade of life and frequented the periorbital region. Dermoid cyst accounts for less than $0.01 \%$ of the cysts occurring in the oral cavity. ${ }^{13}$ It usually occurs in the second to third of life as asymptomatic swelling and plunging ranula is the most common differential diagnosis. These findings are consistent with our study. ${ }^{13,14}$

Dermoid cysts arising in the midline nasal area are commonly associated with fistula formation that connects the underlying cyst to the skin surface. Congenital dermal sinuses are reported to arise in the scalp and anterior chest wall. ${ }^{4}$ Dermoid cyst rarely occurs in the gluteal region and only a handful of cases of dermal sinus over the lateral aspect of the gluteal region are reported. ${ }^{15,16}$ In the present study we reported a case of a pediatric dermoid cyst with sinus formation in the left gluteal region. The differential diagnosis for buttock sinuses includes fistula in ano.

Usually, cutaneous cysts remain asymptomatic but sometimes they may rupture resulting in inflammation, infection, or sinus formation. In a study by Kamyab et al. ${ }^{6}$ complications such as infection, inflammation, the rupture was reported in $17.8 \%$ of cases. Similar complications of cyst rupture, inflammation, and sinus tract formation were seen in $14.49 \%$ of cases in our study.

Trichilemmal cyst occurs as asymptomatic cutaneous or subcutaneous swelling. The scalp is the most common site and shows female predominance. ${ }^{4}$ Similar findings were reported in the present study. The uncommon site for trichilemmal cyst in the present study was the postauricular and anterior midline neck region. Cholesterol cleft is a common finding in trichilemmal cysts. In our study cholesterol granuloma was reported in $25 \%$ of cases.

Proliferating trichilemmal cysts(PTC) are generally large in size measuring more than $2 \mathrm{~cm}$ in diameter and usually occur in an adult female with a predilection for the scalp. ${ }^{4}$ In contrast to this, in our study PTC occurred over the back of an adult male as fungating mass. In a study by Sau P et al. ${ }^{17}$ the most common site of PTC was the scalp (49 cases, $78 \%$ ). They also reported five cases of PTC over back. In their study skin was intact in maximum cases and only a few cases presented as fungating mass.

Apocrine hidrocystoma is an adenomatous cystic proliferation of apocrine glands. Most frequently they occur on the face as small papule or nodule in middle-aged to elderly patients. They usually measure 1-3 millimeters in diameter and rarely exceed more than $1 \mathrm{~cm}$ in size. In the present study, the unusual presentation of apocrine hidrocystoma was that it was giant measuring $3 \mathrm{~cm}$ in diameter, occurred over back in a young woman. Only a few cases of giant apocrine hidrocystoma on the back are reported in English literature. ${ }^{18,19}$ Kamyab et al. ${ }^{6}$ reported 75 cases $(3.6 \%)$ of apocrine hidrocystoma with a slight male predominance $(52 \%)$, and the most common location was face $(81.3 \%)$.

Cysticercosis of the scalp is commonly reported as a part of disseminated cysticercosis presenting as subcutaneous nodules of varying size all over the body in association with neurocysticercosis. ${ }^{20,21}$ In the present study, since the patient with scalp cysticercosis was otherwise asymptomatic and there was no clinical suspicion of cysticercosis, an imaging study of his brain was not performed. 
Cutaneous endometriosis is a very rare condition usually comprising up to $1 \%$ of total cases. ${ }^{22,23}$ Cutaneous endometriosis is defined as the abnormal presence of the endometrial gland and stroma in the skin. It can present either as primary or spontaneous endometriosis or as secondary scar endometriosis in patients with a previous history of abdominal surgery. Primary spontaneous endometriosis is known to be associated with pelvic endometriosis however this association is less frequent in cases of scar endometriosis. It predominantly occurs in women of reproductive age group and presents as soft to firm nodule or papule. The patients commonly give a history of cyclic pain in swelling associated with the menstrual cycle. ${ }^{22}$ Definitive diagnosis is possible by histopathological examination that demonstrates the presence of both normal endometrial gland and stoma. In our case there was no clinical suspicion of endometriosis as a history of cyclic pain was not elicited.

Kamyab et $a .^{6}$ reported malignancy in 45 cases with a clinical diagnosis of a cutaneous cyst. In our study, a good clinicopathological correlation (91.89\%) was observed. In most cases, the diagnosis was obvious on gross examination since a majority of the cutaneous cysts contained grumous, thick toothpaste-like foul-smelling keratin material. However, by submitting cutaneous cysts cases to routine microscopic examination some interesting findings like cysticercosis and cutaneous endometriosis were reported.

\section{CONCLUSIONS}

The present study enhanced our knowledge regarding the unusual clinical presentation of various cutaneous cysts. In the majority of the cases, a definitive diagnosis can be made clinically. However, some cases with secondary complications like sinus formation can clinically raise suspicion of infective etiology like tuberculosis. Rare cases like apocrine hidrocystoma, proliferating trichilemmal cyst, or cysticercosis with unusual clinical presentation can pose a diagnostic dilemma. In such cases, definitive diagnosis is only possible upon histopathological analysis.

\section{REFERENCES}

1. Kaya G, Saurat JH. Cutaneous adnexal cysts revisited: what we know and what we think we know. Dermatopathology 2018;5(2):79-85. Crossref

2. Elder DE, Elenitsas R, Johnson BL, Murphy GF, Xu X. Tumors and cysts of the epidermis. In: Elder DE (ed.) Lever's Histopathology of the Skin.10th ed. China: Lippincott Williams and Wilkins, 2009; p. $800-2$.

3. Elder DE, Elenitsas R, Johnson BL, Murphy GF \& Xu X. Metabolic diseases of skin. In: Lever's Histopathology of the Skin.10th ed. China: Lippincott Williams and Wilkins, 2009; 437

4. Weedon D, Strutton G, Rubin A. cyts, sinuses and pits.In: Weedon's Skin Pathology. 3rd ed. Edinburgh: Churchill Livingstone/Elsevier; 2010: p442

5. Al-Khateeb TH, Al-Masri NM, Al-Zoubi F. Cutaneous cysts of the head and neck. J Oral Maxillofac Surg. 2009;67(1):52-7. Crossref
6. Kamyab K, Kianfar N, Dasdar S, Salehpour Z, Nasimi M. Cutaneous cysts: a clinicopathologic analysis of 2,438 cases. Int J Dermatol. 2020;59(4):457-62. Crossref

7. Lincoski CJ, Bush DC, Millon SJ. Epidermoid cysts in the hand. J Hand Surg Eur Vol. 2009;34(6):792-6. Crossref

8. Syed MMA, Rajbhandari A, Paudel U. Idiopathic calcinosis cutis of the scrotum: a case report and review of the literature. J Med Case Rep. 2018;12(1):366. $\underline{\text { Crossref }}$

9. Saad AG, Zaatari GS. Scrotal calcinosis: is it idiopathic? Urology. 2001;57(2):365. Crossref

10. Kelten EC, Akbulut M, Colakoglu N, Bayramoglu H, Duzcan SE. Scrotal calcinosis: It is idiopathic or dystrophic. Aegean Pathol J. 2005;2:4-7. Website

11. Paliotta A, Sapienza P, D'Ermo G, et al. Epidermal inclusion cyst of the breast: A literature review. Oncol Lett. 2016;11(1):657-660. Crossref

12. Chandanwale SS, Buch AC, Kumar H, Mishra N. Epidermoid cyst in the breast:A common benign lesion at a rare site. Clin Cancer Investig J 2015;4:99-101 Website

13. Vieira EMM, Borges AH, Volpato LER et al. Unusual Dermoid Cyst in Oral Cavity. Case Reports in Pathology 2014(2):389752. Crossref

14. Lima Jr. SM., Chrcanovic BR, de Paula AMB, Freire-Maia B, Souza LN. Dermoid cyst of the floor of the mouth. The Scientific World Journal 2003;3:156-62. Crossref

15. Nishimon M, Shimizu Y, Ueno M, Iwanami A. Late-onset congenital lateral dermal sinus tract. BMJ Case Rep. 2014;2014:bcr2014206530. $\underline{\text { Crossref }}$

16. Hosokawa T, Tanami Y, Sato Y, Oguma E. Image findings of dermal sinus in the lateral buttocks. Radiol Case Rep. 2020;15(5):586-591. Crossref

17. Sau P, Graham JH, Helwig EB. Proliferating epithelial cysts. Clinicopathological analysis of 96 cases. J Cutan Pathol. 1995;22(5):394-406. Crossref

18. Holder WR, Smith J, Mocega EE. Giant Apocrine Hidrocystoma. Arch Dermatol. 1971;104(5):522-3. Crossref

19. May C, Chang O, Compton N. A giant apocrine hidrocystoma of the trunk. Dermatol Online J. 2017 Sep 15;23(9):13030/qt8bm3r2h4. Website

20. Singrodia S, Joshi RG, Solanki RB, et al. Neuro cysticercosis with subcutaneous nodules. (Letter to the editor) Indian J Dermatol Venereol Leprol. September-October 2009;75( 5): 524-5. Crossref

21. Gonju D, Sarkar K, Haldar SN, Pramanik N. A rare case of disseminated cysticercosis. Ann Trop Med Public Health 2015;8:2902. Website

22. Agarwal A and Fong Y F. Cutaneous endometriosis. Singapore Med J 2008; 49(9):704-09. Crossref

23. Raffi L, Suresh R, McCalmont TH, Twigg AR. Cutaneous endometriosis. Int J Womens Dermatol. 2019;5(5):384-6. Crossref 